\title{
Editorial: Invention and Necessity
}

Frederic Raphael is primarily a novelist, and his power of conveying truth by way of fiction is at work in his Parkes 25th Anniversary Lecture, recently delivered at the University of Southampton. The lecture as a whole is not of course a work of fiction, but it rests on one substantial invention-the supposition that there exists a book entitled The Necessity of Anti-Semitism. Mr Raphael notes the precedent of Shelley's The Necessity of Atheism and acknowledges the origin of his tactics in the work of Jorge Luis Borges. We are not meant to identify Mr Raphael's own lecture with the invented book, even though the lecture itself is called 'The Necessity of Anti-Semitism'. We must take even more care than usual to remember the differing implications of italic type and of quotation marks.

The device he has adopted allows Mr Raphael to distance himself from some of the ambiguities and hyperboles and audacities in which 'our author' indulges. Our author-Mr Raphael himself-is uncommitted by even the most explicit and emphatic utterances of his imaginary colleague. After all, Shakespeare did not murder Duncan, and though Milton shares in the sin of Adam he is not responsible for all the words and works of Lucifer. The author of 'The Necessity of Anti-Semitism' writes this about the author of The Necessity of Anti-Semitism:

We are by now aware that our author trades-perhaps revels-in ambiguities. He sees the Jews as both like and unlike other men, both part of Europe and external to it, both assimilable and indigestible. He may still claim here that he is simply trying to clarify a situation, not to propose an aetiology, yet he will be disappointed if we have not picked up several clues as to what is to come. Surely we are supposed to recognize an attempt at least to indicate why anti-Semitism is not a sad contingency or even a disagreeable contagion, but a constant and essential working part of Europe's unreformed logic.

The nature of the besetting uncertainties may be focused by an example based on but not drawn from a passage in Mr Raphael's text. During the last war many Jews felt an understandable 'desire to fight under their own flag, and in an exclusively Jewish regiment, against the Nazis'. 'Our author' detects ambiguities that are grist to his mill in the fact that Churchill's wish to honour this desire met with resistance from some of his colleagues. Is there not a hidden 'heads you lose' syndrome in the minds of the opposition? Jews are condemned either to be represented by a military unit whose creation is alarming to some 


\section{Editorial}

prejudiced minds, or to be a homogeneous body of 'defenceless and incurably civilian Jews' whose condition would be found contemptible by the same or other prejudiced minds. Mr Raphael recognizes that the reverse of this coin is of the same metal, and 'our author' goes on to apply the syndrome to the State of Israel: 'what', he asks, 'shall we say of Israel's fundamental reluctance to conscript its Arab citizens? Is that different? How different? Comfortably or uncomfortably? Should these questions not be asked? Why?' Our own reflections may widen the scope of the questions still further. Theodore Roosevelt's determination to exclude all possibility of 'hyphenated Americans' has come to be frustrated and reprobated as a great number of modern Americans strenuously combine ethnicity with loyalty to the US Flag. Then there are-or may one day be-black sections in the Labour Party, and in general a continuing dialectic in pluralist and multi-cultural societies between the assimilation and the particularism that are at the heart of so much of what 'our author' and our author wish to set before us. It is no wonder that $\mathrm{Mr}$ Raphael speaks of seeing through a glass, darkly, and remembers the dictum of Heraclitus that the only wise one both is and is not willing to be called by the name of Zeus. 